\title{
The Role Of Social Media In Crisis Management At Carnival Cruise Line
}

\author{
Kathleen R. Bryce, Hodges University, USA
}

\begin{abstract}
This research provides an overview of the marketing issues facing Carnival Cruise Line after several high profile incidents. Carnival Cruise Lines has suffered several mishaps which have harmed its reputation and the reputation of the cruise industry in general. Is the damage irreparable, or can careful crisis management and marketing repair the trust and confidence of Carnival's guests and prospective cruisers? The latest disaster, an engine room fire which left the Carnival Triumph adrift in the Gulf of Mexico earlier this year prompted the Cruise Lines International Association (CLIA) to approve a "Cruise Industry Passenger Bill of Rights" ("Cruise Industry Adopts," 2013). This research offers insight into the use of social media as both a positive and negative marketing tool.
\end{abstract}

Keywords: Carnival; Social Media; Stakeholders; Utility; Marketing; Leadership; Cruisers; Passengers; Press; Cruise Line; Ship; Public Relations; Information Technology; Media; Crisis Management

\section{INTRODUCTION}

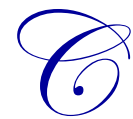

arnival Cruise Lines is known in the cruise ship industry as the "Fun Ships" and leader of low-priced family-oriented cruise vacations. Carnival recently suffered more than its fair share of mishaps. Beginning with the inaugural cruise of Carnival's first ship TSS Mardi Gras running aground on a sandbar to the recent Carnival Triumph engine room fire earlier this year that left the ship stranded in the Gulf of Mexico for five days, crisis management has been an unwelcome yet familiar process of the world's largest cruise line.

Table 1: Timeline of Carnival Cruise Ship Calamities

\begin{tabular}{|c|c|c|c|c|c|c|c|c|}
\hline $\begin{array}{c}\text { March } \\
1972\end{array}$ & $\begin{array}{l}\text { June } \\
1995\end{array}$ & $\begin{array}{l}\text { July } \\
1998\end{array}$ & $\begin{array}{c}\text { September } \\
1999\end{array}$ & $\begin{array}{c}\text { January } \\
2012\end{array}$ & $\begin{array}{c}\text { November } \\
2012\end{array}$ & $\begin{array}{c}\text { February } \\
2013\end{array}$ & $\begin{array}{c}\text { March } \\
2013\end{array}$ & $\begin{array}{c}\text { March } \\
2013\end{array}$ \\
\hline $\begin{array}{c}\text { Carnival } \\
\text { Mardi Gras }\end{array}$ & $\begin{array}{c}\text { Carnival } \\
\text { Celebration }\end{array}$ & $\begin{array}{l}\text { Carnival } \\
\text { Ecstasy }\end{array}$ & $\begin{array}{l}\text { Carnival } \\
\text { Tropicale }\end{array}$ & $\begin{array}{c}\text { Costa } \\
\text { Concordia }\end{array}$ & $\begin{array}{l}\text { Carnival } \\
\text { Splendor }\end{array}$ & $\begin{array}{l}\text { Carnival } \\
\text { Triumph }\end{array}$ & $\begin{array}{c}\text { Carnival } \\
\text { Dream }\end{array}$ & $\begin{array}{l}\text { Carnival } \\
\text { Legend }\end{array}$ \\
\hline $\begin{array}{l}\text { Ran } \\
\text { aground on } \\
\text { maiden } \\
\text { voyage }\end{array}$ & $\begin{array}{l}\text { Engine } \\
\text { room fire }\end{array}$ & $\begin{array}{l}\text { Laundry } \\
\text { room fire }\end{array}$ & $\begin{array}{l}\text { Engine } \\
\text { room fire }\end{array}$ & $\begin{array}{l}\text { Struck a } \\
\text { reef and } \\
\text { partially } \\
\text { sank }\end{array}$ & $\begin{array}{l}\text { Engine } \\
\text { room fire }\end{array}$ & $\begin{array}{l}\text { Engine } \\
\text { room fire }\end{array}$ & $\begin{array}{l}\text { Technical } \\
\text { malfunction } \\
\text { of emergency } \\
\text { generator }\end{array}$ & $\begin{array}{c}\text { Technical } \\
\text { malfunction } \\
\text { affecting } \\
\text { sailing } \\
\text { speed }\end{array}$ \\
\hline
\end{tabular}

As noted in Table 1, the two mentioned incidents are not the only serious issues experienced by Carnival over the past several years. Additionally, in the recent past, Carnival Cruise Line has endured high profile media issues including a pirate attack, person overboard, person missing, death, virus outbreak, rape, collision, and robbery. The manner in which each incident is handled is paramount to the continued confidence of current passengers and future cruisers.

This research will examine the crisis management processes of Carnival Cruise Lines. Additionally, it will examine the function of information technology and marketing in public relations following a breakdown in Carnival's mission, whether caused by human error, technical or mechanical failure, or forces of nature. This research will also examine the positive and negative impact of social media on a business enterprise. 


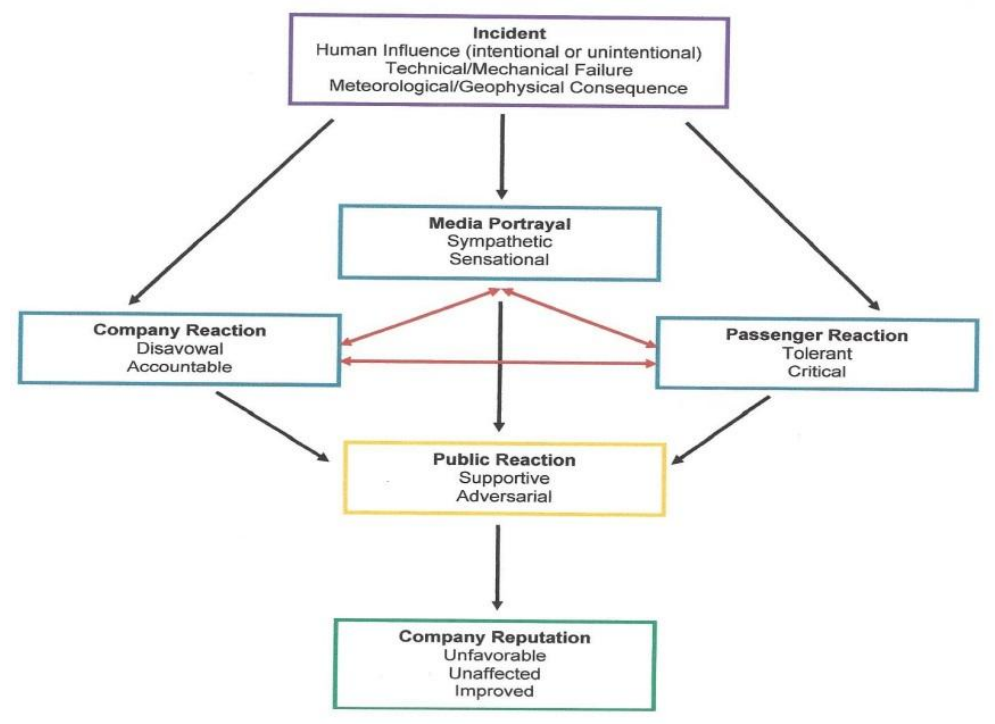

Figure 1: Conceptual Framework

The conceptual framework depicted in Figure 1 illustrates how an incident and the course of action selected by management can affect the company image. This research will outline action taken by Carnival Cruise Line to various incidents and the lessons learned from different approaches to crisis management.

\section{THE ISSUE}

Carnival Corporation is the undisputed number one cruise operator in the world. Carnival's fleet includes 102 ships scattered among ten cruise lines that operate in a global marketplace ("Corporate Fact Sheet," n.d.). This research is on the corporation's flagship, Carnival Cruise Lines ("Carnival Cruise Lines," n.d.). Carnival's popularity has suffered in the past 18 months due to the incidents depicted in Table 1 and how they were handled.

There were several major incidents that compounded the impact of the normal yearly cruise line issues covered earlier in this paper. The biggest incident was the Costa Concordia running aground in January 2012 off the coast of Italy. The ship listed severely and partially sank causing the death of several passengers and questioning the Captain and crew's actions. More than 4,000 passengers and crew were evacuated (Banks, 2012), and 32 people were killed in the tragedy (Nadeau, 2013). The second major incident was a fire in the engine room of the Carnival Triumph in February 2013 causing the ship to lose propulsion and leaving her adrift in the Gulf of Mexico. Although there were no injuries, passengers reported deplorable conditions including a 4-5 hour wait for food, no air conditioning, and non-working toilets (Wilkinson, 2013).

Complicating Carnival's problems was the fact that these incidents appeared to be handled differently by management. Costa's earliest reports did not claim responsibility, but called it an "incident," expressed sadness for the victims, and stated that the situation needed to be investigated for cause. The third report, 48 hours after the accident, suggested that human error may have been the cause, and reiterated passenger and crew safety as their priority (Banks, 2012). News and TV reports sensationalized the accident while sharing many more details than the actual press releases from Carnival. It is important to note that the two mentioned major incidents were vastly different types of crises. The Concordia incident was human error while the Triumph event was attributed to a mechanical failure. Both required immediate and decisive action from management. Both were approached with different methodologies.

In 2007 Coombs developed a Situational Crisis Communication Theory (SCCT) to assist crisis communication teams in protecting their company reputation following a crisis (Coombs, 2007). Eastern Illinois University professor, W. Timothy Coombs has been often cited for his work with crisis communication management. This research illustrates how the SCCT could aid Carnival Cruise Lines with crisis management. 
The SCCT states that an individual will consider many variables when forming his or her opinion following a disaster. The first variable is the nature of the disaster. SCCT separates the crises into three categories as indicated in Table 2. The more accountable the corporation is for the incident, the more damage it can expect from stakeholder opinion (Coombs, 2007).

Table 2: Types of Crises

\begin{tabular}{|c|c|c|c|}
\hline Victim: Company is also a casualty & $\begin{array}{l}\text { Natural Disaster: weather-related or } \\
\text { geophysical } \\
\text { Rumor } \\
\text { Violence of current or former employee } \\
\text { Product Tampering }\end{array}$ & & $\begin{array}{l}\text { Company is } \\
\text { less liable }\end{array}$ \\
\hline Accident: unintentional & $\begin{array}{l}\text { Challenges: Stakeholder claim of } \\
\text { inappropriate action of company } \\
\text { Mechanical or Technical Error: } \\
\text { unintentional }\end{array}$ & Carnival Triumph & \\
\hline Preventable: & $\begin{array}{l}\text { Human Error } \\
\text { Corporate Deception: with or without } \\
\text { damage/injury } \\
\text { Corporate Misconduct: regulation } \\
\text { violation }\end{array}$ & Costa Concordia & $\begin{array}{l}\text { Company is } \\
\text { more liable }\end{array}$ \\
\hline
\end{tabular}

The method in which corporations react to past crisis sways public perception of a current situation. Previous episodes involving Carnival ships have elicited deniability and blame from Carnival's corporate team. Carnival stands out because: 1) it is the largest cruise line ("Corporate Fact Sheet," n.d.), and 2) it is the most advertised cruise line (Kwortnik, Jr., 2006). Carnival carved their niche in the market as the cruise line that provides a "good quality, affordable vacation" that focuses on the "Fun Ship," rather than the destination. This premise attracts a young, first-time cruiser. The price point average of $\$ 175$ per person per day is significantly lower than the industry average. In 2006, Carnival's senior vice president of marketing, Terry Thornton, stated "We're perfectly happy to be the Wal-Mart of the cruise industry" (Kwortnik, Jr., 2006).

Coombs agrees that crisis history is a noteworthy aspect that can influence public opinion (Coombs, 2004). This is an important factor of SCCT. George Santayana stated, "Those who do not learn from history are doomed to repeat it" ("Famous Quotes," n.d.). It appears that Carnival has paid attention and learned.

An example of Carnival's awareness of past mistakes during the Costa Concordia accident was crisis team reaction to the Carnival Triumph incident. Almost immediately following the engine room fire and loss of propulsion on the Carnival Triumph, posts began appearing on Facebook about the incident... not from passengers, but from Carnival staff! Carnival used social media as a way to keep the public informed up to the minute, rather than trying to spin it to its advantage. This response was a total about-face for the company. The cruise line accepted responsibility and reiterated its commitment to the passengers' and crew's safety. This was an effective communication strategy. Public ascription to a crisis will differ depending on the cause (natural, man-made, technical), and company acknowledgement (Coombs \& Holladay, 2002). In this case, the disaster was technical/mechanical and unintentional. This would be more favorable to Carnival's reputation in terms of public perception.

Carnival had successfully created an effective initial response to the Triumph cruise ship's fire. However, this particular incident worsened by the day. Power could not be restored thus necessitating that the ship be towed to the nearest port of Progreso, Mexico. Carnival immediately announced generous restitution to its passengers. Future voyages on the Triumph were canceled and those stakeholders were reimbursed. Limited emergency generator power was restored that provided restricted hot food service. To compound problems, only a few toilets were operational. The lack of propulsion of the ship allowed the Triumph to drift critically off-course. This change required that the ship to be towed to Mobile, Alabama instead of Progreso (Carnival, 2013).

The public received this information on Facebook more rapidly than the television news could produce it. Initially, with Facebook providing the ability for passengers to comment, much of the Facebook response was 
favorable to Carnival. Additionally, past Carnival guests came to the cruise line's defense, stating that Carnival was bending over backwards to accommodate its passengers during this awful situation.

As conditions continued to deteriorate, passengers aboard the crippled vessel began tweeting and posting numerous uncomplimentary sentiments on Facebook. Passengers forced to use a plastic bag for a toilet were less charitable with comments. The unique element in this situation was that the public was receiving reports from both the company and the victims as the crisis unfolded, rather than after it was over. Carnival learned a valuable lesson on the use of social media.

It is uncertain if Carnival's initial comments on social media were the best response. Pennsylvania State University professor Anna Mattila suggests that when a company apologizes for an incident or openly bears accountability it opens the door for legal consequences (Mattila, 2009; Coombs \& Holladay, 2002, et. al.).

Any crisis involving a large company will have legal implications. The larger the incident, the more victims there will be. Accidents with multiple victims are more costly for the company in terms of restitution. Coombs and Holladay (2002) indicate that companies should not advocate apologizing and accepting responsibility in every situation (Coombs \& Holladay, 2002). Utilization of the SCCT to evaluate the cause of the crisis, the response of the stakeholders in previous crises (history), and the financial and legal implications of the disaster prior to making a statement are suggested.

The media plays a tremendous role in the shaping of public opinion regarding any disaster, and Carnival's troubles are no exception. The public received the information differently for the two major incidents. The Concordia disaster was a TV media event, while the Triumph played out nearly in real time on the Internet. Public relation experts Seon-Kyoung An, Karla Gower, and Seung Ho Cho suggest that the news media shapes our perception most often (An, Gower, \& Cho, 2011), and that may have been true in 2007, and even in 2012, but the use of social media regarding the Triumph, both by Carnival and by the victims created a unique situation. Coombs (2007) stresses the importance of quickly connecting with the news media to communicate the details which effectively makes the media a crisis response partner. In this case, it is likely that the news media received first notice of the Triumph's fire and subsequent distress from Facebook. At that point, it was the public, Carnival's employees, passengers, passengers' family members, and anyone else with an opinion and Internet access that formed the media's perception of the disaster.

The first concern of the company must be the physical safety and welfare of the passengers and crew (stakeholders); SCCT focuses on safeguarding the company's standing. Coombs surmises that there are three goals when guarding the company's reputation following a crisis: 1) sculpt the acknowledgement of the incident, 2) modify the views of the company, and 3) diminish the harmful influence created by the event (Coombs, 2007). This is the premise of SCCT. In order to meet these objectives, the crisis must first be categorized (see Figure 2.1). SCCT hypothesizes that the type of crisis can assist in determining the appropriate crisis response.

In the SCCT, three elements comprise the company's reputation: 1) crisis responsibility, 2) company crisis history, and 3) previous crisis stakeholder/company relationship. Assessing the potential effect on reputation combined with the crisis type, the Triumph incident was an unintentional mechanical failure for which Carnival took responsibility. Carnival has had crises of all types in the past, but their relationship during crises with stakeholders has been less favorable. Due to public response to the Concordia crisis in a relatively short time span, this research indicates that Carnival utilized social media quickly for the Triumph incident to keep its stakeholders informed on its own terms, rather than risking the anticipated media spin. SCCT does a good job of linking crises and responses, but accepts that it is not a foolproof method of eliminating or reducing damage to a company's reputation. SCCT is, rather, a guideline or a plan to help safeguard the reputation (Coombs, 2007).

\section{METHODOLOGY}

With the strict limitations of time and expense for this project, the methodology used for this research was a very casual survey posted on Facebook consisting of six close-ended questions specifically related to the Costa Concordia and Carnival Triumph disasters. The post requested that recipients share the short survey with their 
contact list in order to have a large sample to include participants not personally known to the researcher. The same questionnaire was also emailed to acquaintances. The following questions were used.

1. Have you been on a 3-day or longer cruise?

2. Have you heard of the Costa Concordia disaster?

3. Have you heard of the Carnival Triumph disaster?

4. Has either of these incidents influenced your opinion of cruising?

5. Has either of these incidents influenced your opinion of Carnival?

6. As compensation, passengers received a full refund of the cruise + all transportation expenses, a future cruise credit equal to what they paid for the cruise, reimbursement of all shipboard expenses except gift shop and casino purchases, travel and hotel accommodations once they returned to port, $+\$ 500$ cash per person. Could Carnival done more in terms of compensation?

There were 48 individuals that responded to the survey. Most but not all respondents were personally known to the researcher. There were no qualifying questions; it was a public survey. Question 6 resulted in fewer than 48 responses because some participants left the question blank. Despite the request that participants answer yes or no to the questions, several suggested alternative compensations or opined on this question without answering directly.

\section{ANALYSIS}

Respondents to the survey were stakeholders of Carnival as every respondent is either a cruiser or a potential cruiser. Carnival's target market for advertising is the first-time cruiser (Kwortnik Jr., 2006). Two-thirds of the survey's respondents have been on at least one 3-day or longer cruise.

Table 3: Survey Results

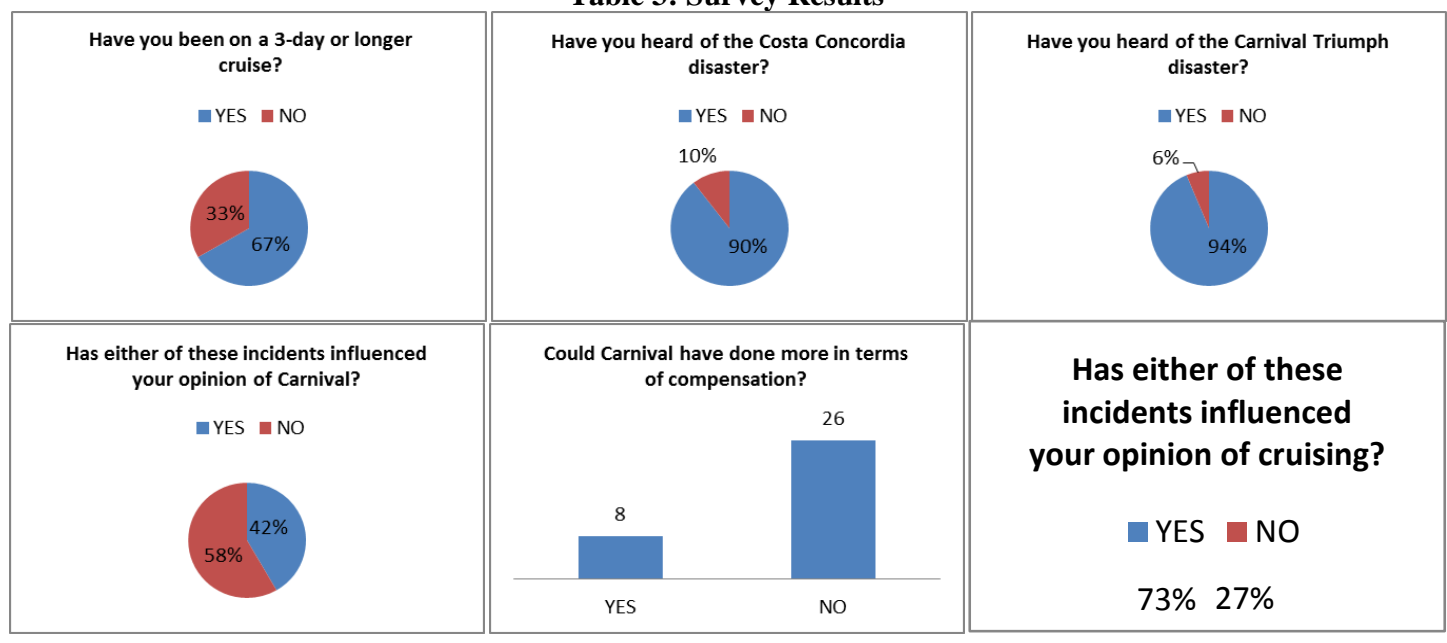

As noted in the results listed in Table 3, the majority of participants have heard of both disasters. Slightly less had heard of the grounding of the Costa Concordia. This could be attributed to the fact that the line is an Italian line (owned by Carnival) and the incident took place overseas. Also, it is reasonable to assume that most of the respondents were in the United States, from which the Triumph cruise left its port. It is probable that none of the respondents were passengers on either the Costa Concordia or the Carnival Triumph at the time of the reported incidents. This researcher was unable to get a response from a known passenger of either disaster.

It appears from this unscientific survey that Carnival's popularity was affected more than cruising in general. Due to Carnival being the world's largest cruise line and the most advertised cruise line (Kwortnik, Jr., 2006), public opinion can be swayed based on hearsay rather than fact. 
A professor at Cornell University School of Hotel Administration, Dr. Chekitan Dev (2006) prepared an excellent SWOT analysis for Carnival Cruise Line to help them in the time of crisis management. Carnival made many improvements recommended by Dr. Dev. A good example was improving its Customer Relationship Management (CRM) system (Dev, 2006). Carnival utilizes customer relations software on its website to interact with its past and currently-booked guests which will assist in protecting its brand with that segment of the population. The opportunity for Carnival is to work on disassociating itself with the identity of "the Kmart of the Caribbean" (Kwortnik, Jr., 2006) or "the Wal-Mart of the cruise industry" (Kwortnik, Jr., 2006).

\section{CONCLUSION}

To strengthen this research, Carnival was contacted at the beginning of this project, with specific questions regarding these two incidents. The Public Relations department responded to the request and provided a Carnival Cruise Lines fact sheet, and a list of trade publications to be used for research. A second attempt was made through social media in hopes of contacting any Carnival staff members who would be willing to provide insight into how Carnival manages crises. Mischelle Beattie from Carnival's PR department replied and requested that I email my questions. Aly Bello-Cabreriza, Public Relations Manager for Carnival Cruise Lines responded to the email and stated that Carnival was unable to respond to my questions, but provided three press releases relating to the Triumph fire.

Bello-Cabreriza stated that Carnival does have a crisis communications team, and that Carnival uses two outside PR agencies. Because this research was unable to include exclusive information from Carnival regarding its crisis management strategies, the data in this report was compiled from previous research, interviews of travel industry professionals and cruise passengers, as well as public opinion. Therefore, recommendations may be broadspectrum.

Coombs (2007) suggests that SCCT is substitute for case studies in recognizing how to protect reputational assets during a crisis. An, Gower, and Cho (2011) claimed that SCCT doesn't take into consideration the impact of the news media on the public's perception of the crisis and the company's response strategy. This research indicates that the most effective method of protecting or repairing one's reputation is a combination of all strategies. SCCT is a great list to start with, but the relationship with the news media cannot be ignored. It should be constantly nurtured in hopes of favorable treatment during crises. An, Gower, and Cho also recommend evaluating past crisis handling. Carnival should consider including an analysis of competitors' similar crises.

The same questions that were requested of Carnival were answered by a Security Supervisor (his identity is kept confidential at his request) of a large casino cruise ship. The ship carries 1,500-1,700 passengers and 500-600 crew members on seven decks. In comparison, the Costa Concordia had a passenger capacity of 3,570 and a crew of 1,000 with 13 passenger decks; the Triumph's passenger capacity is 2,758 and a crew of 1,100 with 12 decks ("Shipstips"). He could at least give some insight on his own experience with crisis management aboard his ship. His crisis management team consisted of the ship's Captain, Section Directors, and security staff. The ship prepared by staging mock disasters with the crew every two weeks. Disasters that occurred while he was aboard were fires, medical emergencies, bomb threats, and hurricanes. The team did not have a plan for reputation repair following a crisis; it concentrated wholly on safety.

The function or goal of the crisis management team is damage control during and following a crisis. The protection of the company's reputation is crucial not only for profit, but for sustaining business. The company's Chief Executive Officer should be the primary leader. The company's attorneys should have a strategy for defense or settlement, depending on the crisis. The accounting department should have information at its fingertips to anticipate financial damage and the strength of accounts. Depending on the type of crisis and number/state of victims, reparations will be necessary. The company cannot afford to over-accommodate; not only could it be harmful financially but it could imply that the crisis is worse than it appears (Coombs, 2007). The greater the disaster, the more the company must accommodate; the more accommodation, the more costly for the company (Coombs \& Holladay, 2002). The public relations department has the marketing experts required for crisis management. 
Research makes it clear that Carnival made personnel changes between crises. Carnival appears to have learned from the two major incidents. One's brand isn't likely to be completely destroyed with one catastrophe, nor will it be repaired with one well-handled. The use of Facebook as a strategy for the Triumph disaster showed bravery in choosing a media that was unfamiliar. There were certainly challenges to the decision; Carnival gave up control by going so public. The cruise line may have to answer to the news media as it sidestepped normal channels and went directly to the public, which was a bold (and in this researcher's opinion, brilliant) move. Carnival still gave out only the information that it wanted to be made public, but left it wide open for rumors as well. Anyone with Internet access can log on and tell the world anything they want; facts, fiction, opinions... there is no filter between what's posted and what's taken away. Carnival took a chance, and it's seeing its share of negative posts. What we saw, however, were loyal devotees of the cruise line coming to its defense, just as publically as its opponents. It will be interesting to see how the next incident is handled.

\section{AUTHOR INFORMATION}

Kathleen "Kitty" Bryce is a recent graduate of Hodges University, and currently studying for her Masters degree in Professional Studies. A veteran of the United States Air Force, Kitty has traveled all over the world and enjoys sharing her experiences and life's lessons with others through writing and speaking. She is an advocate of higher education, and is employed by her alma mater. E-mail: kbryce@ hodges.edu

\section{REFERENCES}

1. An, S. K., Gower, K. K., \& Cho, S. H. (2011). Level of crisis responsibility and crisis response strategies of the media. Journal of Communication Management, 15(1), 70-83. Retrieved from http://search.proquest.com/docview/849331590?accountid=40795

2. Banks, B. (2012, January 15). Costa cruises statement on Costa Concordia update.

3. Carnival Cruise Lines. (n.d.). Retrieved from http://www.cruising.org/cruiseline/carnival-cruise-lines

4. Carnival Triumph Fire Timeline (2013). Press release.

5. Coombs, W. T. (2004). Impact of past crises on current crisis communication: Insights from situational crisis communication theory. Journal of Business Communication, 41(3), 265-289. doi: $10.1177 / 0021943604265607$

6. Coombs, W. T. (2012). Ongoing crisis communication: Planning, managing, and responding (3rd ed., p. 2). Thousand Oaks, CA: SAGE Publications, Inc.

7. Coombs, W. T. (2007). Protecting organization reputations during a crisis: The development and application of situational crisis communication theory. Corporate Reputation Review, 10(3), 163-176. Retrieved from http://search.proquest.com/docview/231501136/fulltextPDF?accountid=40795

8. Coombs, W. T., \& Holladay, S. J. (2002). Helping crisis managers protect reputational assets. Management Communication Quarterly, 16(2), 165-186. Retrieved from http://search.proquest.com.hodges.idm.oclc.org/ docview/216315539?accountid=40795

9. Corporate Fact Sheet. (n.d.). Retrieved from http://phx.corporate-ir.net/phoenix.zhtml?c=200767\&p=irolfactsheet

10. Cruise Industry Adopts Passenger Bill of Rights. (2013, May 22). Retrieved from http://www.cruising.org/ news/press_releases/2013/05/cruise-industry-adopts-passenger-bill-rights

11. Davies, A. (2013, March 18). A photo history of carnival cruise ship disasters. Business insider. Retrieved from http://www.businessinsider.com/carnival-disaster-timeline-in-photos-2013-3?op=1

12. Dev, C. S. (2006). Carnival cruise lines: Charting a brand new course. Cornell Hotel and Restaurant Administration Quarterly, 47(3), 301-308. Retrieved from http://go.galegroup.com/ps/ retrieve.do?sgHitCountType=None\&sort=RELEVANCE\&inPS=true\&prodId=PPTH\&userGroupName=int coll\&tabID=T002\&searchId=R1\&resultListType=RESULT_LIST \& contentSegment=\&searchType=Advan cedSearchFormatPosition=1 \&contentSet=GALE|A149214179\&\&docId=GALE|A149214179\&docType=G ALE\&role=\&docLevel=FULLTEXT_WITH_GRAPHICS

13. Famous Quotes. (n.d.). Retrieved from http://www.famousquotesabout.com/quote/Those-who-do$\operatorname{not} / 214658$ 
14. Kwortnik, Jr., R. J. (2006). Carnival cruise lines burnishing the brand. Cornell Hotel and Restaurant Administration Quarterly, 47(3), 286-300. Retrieved from http://infotrac.galegroup.com/itw/infomark/ 794/668/11443466w16/purl=rc1_BIM_0_A149214178\&dyn=3!xrn_1_0_A149214178?sw_aep=intcoll

15. Mattila, A. S. (2009). How to handle pr disasters? An examination of the impact of response type and failure attributions on consumer perceptions. Journal of Services Marketing, 23(4), 211-218. Retrieved from http://hodges.worldcat.org/title/how-to-handle-pr-disasters-an-examination-of-the-impact-ofcommunication-response-type-and-failure-attributions-on-consumer-perceptions/oclc/439819262\& referer=brief_results

16. Rough seas hit carnival's earnings as shares drop. (2013, July 8). Forbes. Retrieved from http://www.forbes.com/sites/zacks/2013/07/08/rough-seas-await-carnivals-earnings-as-shares-drop/

17. Shipstips. (n.d.). Retrieved from http://shipstips.com/

18. Wilkinson, K. (2013, February 15). Carnival triumph: Debarking passengers tell their stories. Cruise news. Retrieved from http://www.cruisecritic.com/news/news.cfm?ID=5208 